\title{
Znaczenie kryteriów biomechanicznych w prawidłowym planowaniu leczenia choroby zwyrodnieniowej stawu kolanowego
}

\section{Significance of biomechanical criteria in proper treatment planning in knee osteoarthritis}

\author{
Andrzej Pozowski, Mateusz Kowal, Andrzej Kierzek, Jadwiga Kuciel-Lewandowska, Marek Tradecki, \\ Małgorzata Paprocka-Borowicz
}

Katedra Fizjoterapii Wydziału Nauk o Zdrowiu Uniwersytetu Medycznego im. Piastów Śląskich we Wrocławiu

ul. Grunwaldzka 2, 50-355 Wroctaw

Kierownik: dr hab. Matgorzata Paprocka-Borowicz

\begin{abstract}
SUMMARY
Introduction: Following the established and unequivocal criteria when choosing the treatment of knee osteoarthritis, despite possibility of precise imaging, is still very problematic. This is partly because doctors of different disciplines: general practitioners, orthopaedic surgeons, rheumatologists, physiotherapists, are involved in the treatment of this disease. For most of them the basic criteria to implement the treatment are: pain and assessment of X-ray in the supine position. As a result of that, despite slight and doubtful improvement, treatment is improperly targeted and extended.

The aim of the study was to prove that the correct diagnosis including biomechanical characteristics of the affected limb, choice of correct treatment, and observance of indications, can shorten treatment, make it more efficient and less expensive. Material and methods: We analyzed of 103 patients qualified for total knee arthroplasty between 2006 and 2011. The
\end{abstract}

\section{STRESZCZENIE}

Wstęp: Realizowanie ustalonych, jednoznacznych kryteriów wyboru metody leczenia choroby zwyrodnieniowej stawu kolanowego (ChZSK), pomimo możliwości precyzyjnego obrazowania, jest nadal problematyczne. Wynika to częściowo $\mathrm{z}$ faktu że terapią zajmują się specjaliści różnych dziedzin: lekarze pierwszego kontaktu, ortopedzi, rehabilitanci, reumatolodzy, fizjoterapeuci czy specjaliści balneologii i medycyny fizykalnej. Dla większości podstawowym kryterium wdrożenia leczenia jest ból oraz ocena standardowego radiogramu, często wykonanego na leżąco. W efekcie leczenie zachowawcze bywa niewłaściwie ukierunkowane i przedłużane pomimo nieznacznej, często wątpliwej poprawy.

Celem pracy było wykazanie, że prawidłowa diagnostyka uwzględniająca sytuację biomechaniczną w chorej kończynie, wybór prawidłowego postępowania terapeutycznego i ścisłe przestrzeganie wskazań może skrócić czas leczenia, czyniąc je bardziej efektywnym i mniej kosztochłonnym.

\section{WSTĘP}

Lata 2000-2010 zostały przez Światową Organizację Zdrowia ogłoszone dekadą kości i stawów. Decyzja ta podyktowana była głównie znacznym statystycznie wzrostem liczby osób indication was primary and advanced knee osteoarthritis in phases III and IV according to Ahlbäcka scale medial displacement of mechanical axis deviation in the lower limb with club-foot (I to IV degrees) and with centre of rotation of angulation (CORA) in the proximal part of the tibia. Only subjects with body mass index under 25 were included in the study. Surveys were used to assess the pre-operative duration of illness, non-surgical methods of treatment and their effects. Final evaluation was made using the Visual Analogue Scale (10-degrees) of pain (during the effort and rest) and gait efficiency 30 days after completed treatment.

Results: The $66.5 \%$ of patients showed no significant improvement in all assessed parameters, which would justify to continuation of the therapy as described above.

Key words: mechanical axis, lower limb, osteoarthritis, stability, osteotomy, physiotherapy.

Materiał i metody: Grupę badawczą stanowiło 103 chorych zakwalifikowanych w latach 2006-2011 do całkowitej artroplastyki kolana z powodu pierwotnej zaawansowanej ChZSK w fazie III i IV wg Ahlbäcka z przyśrodkowym przemieszczeniem osi mechanicznej kończyny dolnej i szpotawością I do IV stopnia oraz środkiem rotacji zagięcia kątowego CORA (center of rotation of angulation) w części bliższej kości piszczelowej. Wskaźnik masy ciała u badanych nie mógł przekraczać 25 . Na podstawie ankiet oceniano okres przedoperacyjny pod kątem czasu trwania choroby, stosowanych metod leczenia zachowawczego oraz ich wyników. Podstawą oceny końcowej były 10-stopniowa skala VAS (Visual Analogue Scale) bólu wysiłkowego i spoczynkowego oraz wydolność chodu po ok. 30 dniach od zakończenia kuracji. Wyniki: U 66,5\% pacjentów we wszystkich ocenianych parametrach nie wykazano istotnej poprawy, która mogłaby uzasadniać kontynuowanie tak prowadzonej terapii.

Słowa kluczowe: oś mechaniczna kończyny dolnej, artroza kolana, stabilność, osteotomia, fizjoterapia.

w starszym wieku borykających się z chorobami zwyrodnieniowymi stawów (ChZS), w tym dużych stawów kończyn dolnych. Bez wątpienia ma to związek z wydłużeniem o kilka lat średniej wieku życia u obu płci w stosunku do lat 50. ubiegłego wieku. 
Choroba zwyrodnieniowa stawów jest schorzeniem postę pującym i jej progresję można jedynie spowolnić. Im większe obciążenia przenosi staw, tym bardziej istotnym staje się optymalne rozłożenie sił nacisku na jego powierzchnię. Utrzymanie prawidłowej biomechaniki stawu kolanowego ma szczególne znaczenie. Powinna ona spełniać 3 podstawowe kryteria: prawidłowej osi mechanicznej kończyny dolnej, stabilności biernej i czynnej oraz zakresu ruchu. Pozwala to na utrzymanie właściwej proporcji pomiędzy ruchem toczenia a ruchem ślizgowym. Nie można przecenić również symetrii przenoszenia i rozłożenia obciążeń przez powierzchnie stawowe w całym zakresie ruchu z zachowaniem jego stopni swobody.

Profilaktyka, fizjoterapia i farmakoterapia są względnie skuteczne i powinny być stosowane do momentu, w którym ich mierzalny, korzystny efekt utrzymuje się przez dłuższy czas. Granicą skuteczności jest okres, gdy staw przestaje spełniać przedstawione powyżej kryteria biomechaniczne. W zależności od stopnia schorzenia, wraz z narastaniem objawów klinicznych i zaburzeń jego biomechaniki zachowawcze leczenie jest coraz mniej skuteczne, a z czasem staje się niecelowe. Jego kontynuowanie można określić jako bezzasadną uporczywą terapię. Jednak nadal niezbędne pozostaje leczenie farmakologiczne oraz fizjo- i balneoterapia w schorzeniach o etiologii zapalnej, zwłaszcza z autoimmunoagresją w tle.

Przedłużanie fizjoterapii, której jedynym uzasadnieniem jest krótkotrwała, najczęściej nieznaczna poprawa, nie powinno być wyłącznym kryterium jej kontynuowania. Często samozadowolenie z własnej działalności przenoszone jest na kartę informacyjną, a wpis „wypisany w stanie poprawy” nie zawsze znajduje obiektywne uzasadnienie. Nie są brane pod uwagę czynniki współdecydujące o poprawie, np. odciążenie w trakcie leczenia ambulatoryjnego czy szpitalnego oraz trudna do określenia ilościowego rola farmakoterapii.

Wzorcowym schematem terapii wieloprofilowej jest udział zespołu ludzi przygotowanych do merytorycznie logicznego planowania kompleksowego leczenia ze szczególnym uwzględnieniem w nim roli fizjoterapeuty i ortopedy. Znaczna większość autorów, bez względu na zastosowane schematy postępowania, korzystnie ocenia wyniki rehabilitacji $[1,2,3,4,5,6$, $7,8,9,10]$. Nieliczni w badaniu wydzielili grupę porównawczą placebo $[5,10]$ lub dokonali randomizacji grup [3]. W ciągu specjalistycznym, jakim jest lekarz pierwszego kontaktu specjalista reumatolog - specjalista ortopeda - specjalista medycyny balneofizykalnej - fizjoterapeuta, każdy powinien mieć wyznaczoną rolę i zakres celów możliwych do realizacji. Pierwszy nie może rozpoczynać terapii bez ustalenia rozpoznania, a często jest ono bardzo trudne. Ostatni musi pamiętać, że dłuższa przerwa w kinezyterapii cofa chorego do punktu wyjścia, natomiast ocena wyniku bezpośrednio po serii zabiegów jest mało wiarygodna.

Celem pracy była ocena stanu biomechanicznego stawów kolanowych oraz przydatności leczenia zachowawczego chorych na ChZS.

Postanowiono wykazać, że prawidłowa diagnostyka uwzględniająca sytuację biomechaniczną w chorej kończynie może ułatwić wybór prawidłowego postępowania terapeutycznego i przełożyć się na skrócenie czasu leczenia, czyniąc je bardziej efektywnym i mniej kosztochłonnym.

\section{MATERIA I METODY}

Grupę badawczą stanowiło 103 chorych, na którą składało się 69 kobiet i 34 mężczyzn w wieku 57-85 lat (średnia 71,1). Czas trwania choroby od pierwszych objawów bólowych do leczenia operacyjnego wynosił średnio 10,3 lat. Najliczniejszą grupę stanowiło $63(61,2 \%)$ chorych z trzecim stopniem zaawansowaniach ChZS wg Ahlbäcka, następnie z czwartym - 36 (34,9\%) i drugim - 4 (3,9\%). Stopień niestabilności oraz wielkość kąta szpotawości stawów kolanowych w grupie badawczej zostały przedstawione w tabeli 1. Posiłkując się 3-stopniową oceną stopnia niestabilności wg O’Donoghue, poszerzono ją do czterech stopni w celu bardziej precyzyjnej oceny grupy badawczej. Miało to na celu lepsze zróżnicowanie rodzajów niestabilności (prosta i złożona) oraz jej wpływu na statykę stawu kolanowego. $87(84,5 \%)$ chorych przyjmowało stale lub w miarę potrzeby leki przeciwbólowe z grupy opioidowych (tramadol) czy znacznie częściej niesteroidowe leki przeciwzapalne (NLPZ): Ketonal, Voltaren, Diclofenac, Rantudil i inne, z różną częstotliwością i w różnych dawkach (brak możliwości oceny statystycznej). Dostawowa farmakoterapia stosowana w leczeniu 53 stawów kolanowych polegała na podawaniu kwasu hialuronowego, u 19 - steroidów, kwasu i steroidów u 15. Z badania wykluczeni zostali chorzy, u których wskaźnik masy ciała przekraczał 25 .

$\begin{aligned} & \text { TABELA 1. Stopień niestabilności oraz wielkość kąta szpotawości } \\
& \text { w grupie badanej }\end{aligned}$
\begin{tabular}{lcc} 
Wielkość kąta szpotawości & $\mathbf{n}$ & $\%$ \\
\hline $5-10^{\circ}$ & 27 & 26,2 \\
\hline $11-20^{\circ}$ & 59 & 57,3 \\
\hline$>20^{\circ}$ & 17 & 16,5 \\
\hline \multicolumn{1}{c}{ Stopień niestabilności } & $\mathbf{n}$ & $\%$ \\
\hline Brak & 26 & 25,2 \\
\hline $\mathrm{I}^{\circ}$ & 15 & 14,6 \\
\hline $\mathrm{II}^{\circ}$ & 52 & 50,5 \\
\hline $\mathrm{II}^{\circ}$ & 10 & 9,7 \\
\hline $\mathrm{IV}^{\circ}$ & 0 & 0 \\
\hline
\end{tabular}

Podstawą oceny końcowej były 10-stopniowa skala VAS (Visual Analogue Scale) bólu wysiłkowego i spoczynkowego oraz wydolność chodu po ok. 30 dniach od zakończenia fizjoterapii.

Nie oceniano bólu spoczynkowego po fizjoterapii ambulatoryjnej, szpitalnej czy sanatoryjnej. Znacznie istotniejsza była ocena możliwości lokomocyjnych - wydolności chodu i bólu wysiłkowego po przejściu ok. $500 \mathrm{~m}$. Czasy utrzymywania się zmniejszonych dolegliwości bólowych znacznie różniły się i określane były na kilka do kilkunastu dni, a u 4 chorych na ponad miesiąc. Te wartości nie zostały poddane ocenie statystycznej. Wszyscy raz lub wielokrotnie poddawani byli 
fizjoterapii z różną częstotliwością, nieliczni leczeniu stacjonarnemu szpitalnemu lub balneo-klimatycznemu. W żadnym z analizowanych przypadków nie wykonano uprzednio leczenia operacyjnego - osteotomii korekcyjnej.

\section{WYNIKI}

U większości chorych z grupy badawczej występował drugi stopień niestabilności z wielkością kąta szpotawości mieszczącym się między $11^{\circ}$ a $20^{\circ}$ (tab. 1). Pomimo znacznego odchylenia osi mechanicznej kończyny dolnej, chorzy z grupy badawczej oceniali nasilenie dolegliwości bólowych występujących w spoczynku jako łagodne bądź stwierdzali ich brak (tab. 2).

Tylko u 9 chorych występował umiarkowany lub silny ból spoczynkowy. Po przyjęciu NLPZ ból spoczynkowy zmniejszył nasilenie i u 60 osób nie wstępował, a u 24 poprawa była znaczna. W przypadku subiektywnej oceny bólu, po przejściu ok. 500 m największa liczba chorych określała występujące dolegliwości bólowe jako umiarkowane (tab. 3). Jako łagodne

TABELA 2. Subiektywna ocena bólu w grupie badawczej przed przyjęciem i po przyjęciu niesteroidowych leków przeciwzapalnych (NLPZ)

Subiektywna ocena bólu spoczynkowego w skali VAS przed przyjęciem NLPZ

\begin{tabular}{lc}
\hline VAS & $n$ \\
\hline Bez bólu & 19 \\
\hline $1-3$ & 59 \\
\hline $4-7$ & 9 \\
\hline$\geq 8$ & 0
\end{tabular}

Subiektywna ocena zmiany w odczuwaniu bólu spoczynkowego w skali VAS po przyjęciu NLPZ

\begin{tabular}{ll}
\hline VAS & $\mathrm{n}$ \\
\hline Brak poprawy & 0 \\
\hline Poprawa nieznaczna 1-2 pkt & 3 \\
\hline Poprawa znaczna 3-5 pkt & 24 \\
\hline Brak bólu & 60 \\
\hline
\end{tabular}

TABELA 3. Subiektywna ocena bólu wysiłkowego przed przyjęciem i po przyjęciu niesteroidowych leków przeciwzapalnych (NLPZ)

Subiektywna ocena bólu wysiłkowego w skali VAS po przejściu ok. $500 \mathrm{~m}$ przed przyjęciem NLPZ

\begin{tabular}{lc}
\hline VAS & $n$ \\
\hline Bez bólu & 1 \\
\hline $1-2$ & 20 \\
\hline $3-5$ & 59 \\
\hline$>5$ & 7 \\
\hline \multicolumn{2}{c}{$\begin{array}{l}\text { Subiektywna ocena zmiany odczuwania bólu wysiłkowego } \\
\text { w skali VAS po przejściu ok. 500 m po przyjęciu NLPZ }\end{array}$} \\
\hline VAS & $n$ \\
\hline Brak poprawy & 0 \\
\hline Poprawa nieznaczna 1-2 pkt & 5 \\
\hline Poprawa znaczna 3-5 pkt & 48 \\
\hline Brak bólu & 34 \\
\hline
\end{tabular}

swoje dolegliwości bólowe oceniało 20 chorych, a 7 osób określiło je jako silne. Również w przypadku subiektywnej oceny dolegliwości bólowych po przejściu ok. 500 m po podaniu NLPZ u chorych z grupy badawczej doszło do zmniejszenia intensywności odczuć bólowych. Najczęściej zgłaszana była znaczna poprawa bądź wyeliminowanie dolegliwości bólowych.

Subiektywne wyniki odczuwanego bólu po leczeniu ambulatoryjnym i sanatoryjnym oceniane po 30 dniach od ich zastosowania nie potwierdziły jednoznacznie skuteczności leczenia zachowawczego (tab. 4). Mniej skuteczna okazała się fizjoterapia ambulatoryjna. Przez 89 chorych z grupy badawczej jej skuteczność została oceniona jako nieznaczna. Tylko u 14 osób doszło do znacznego zmniejszenia dolegliwości bólowych bądź ich wyeliminowania. W ocenie chorych z grupy badawczej większą skutecznością odznaczała się fizjoterapia sanatoryjna. Po 30 dniach od ukończenia leczenia sanatoryjnego u 45 pacjentów z grupy badawczej poprawa była nieznaczna. Natomiast u 58 zmniejszenie dolegliwości bólowych było znaczne lub je wyeliminowano.

TABELA 4. Wyniki subiektywnej oceny bólu po fizykoterapii ambulatoryjnej i sanatoryjnej po przyjęciu niesteroidowych leków przeciwzapalnych (NLPZ)

Subiektywna ocena zmiany odczuwania bólu wysiłkowego w skali VAS po przejściu ok. 500 m po fizykoterapii ambulatoryjnej (10-14 aplikowanych różnych zabiegów) po ok. 30 dniach przed przyjęciem NLPZ

\begin{tabular}{lc}
\hline VAS & $\mathrm{n}$ \\
\hline Brak poprawy & 0 \\
\hline Poprawa nieznaczna 1-2 pkt & 89 \\
\hline Poprawa znaczna 3-5 pkt & 8 \\
\hline Brak bólu & 6
\end{tabular}

Subiektywna ocena zmiany odczuwania bólu wysiłkowego w skali VAS po przejściu ok. 500 m po szpitalnej czy sanatoryjnej kuracji 21-dniowej po ok. 30 dniach przed przyjęciem NLPZ

\begin{tabular}{lc}
\hline VAS & $\mathrm{n}$ \\
\hline Brak poprawy & 0 \\
\hline Poprawa nieznaczna 1-2 pkt & 45 \\
\hline Poprawa znaczna 3-5 pkt & 45 \\
\hline Brak bólu & 13
\end{tabular}

Dolegliwości bólowe chorych z grupy badawczej leczonych w warunkach sanatoryjnych i ambulatoryjnych zmniejszyły intensywność, jednak nie wpłynęły znacząco na ilość przyjmowanych leków przeciwbólowych. Wyniki wskazują na większą przydatność leczenia z wykorzystaniem NLPZ niż poddawania chorych zabiegom fizyko- czy kinezy terapii w warunkach ambulatoryjnych bądź sanatoryjnych.

\section{DYSKUSJA}

Wszelkie dane retrospektywne oparte na subiektywnej ocenie chorego powinno się oceniać z szerszym lub węższym marginesem wątpliwości. Wnioski z opracowanego materiału mogą być dyskusyjne, ponieważ poddanie ich weryfikacji naukowej jest niewystarczające ze względu na brak jednolitych narzędzi. 
Zastosowanie różnych skal, w tym nie w pełni mierzalnych, np. testów nieparametrycznych Wilcoxona i U Manna-Whitneya, powoduje, że wyniki i wnioski z zastosowaniem jednakowych lub bardzo podobnych metod są zaskakująco odmienne. Kujawa i wsp. uznali, że jedna seria zabiegów laseroterapii nie wpływa znamiennie na poprawę aktywności ruchowej i zmniejszenie przyjmowania leków oraz że wszystkie trzy metody leczenia (prądy diadynamiczne, pole magnetyczne, ultradźwięki) cechują się ponad 80\% skutecznością [11]. Analizowane piśmiennictwo, w którym autorzy oceniają oprócz bólu dodatkowo parametry mierzalne, np. ruch czy siłę mięśniową, oparte jest również na założeniu, że badany nie odczuwa bólu i nie ma on wpływu na wynik testu. Lisiński i wsp. uważają, że złagodzenie doznań bólowych najwcześniej występuje w przypadku terapii diadynamikiem [12]. Ponadto skuteczność fizjoterapii oceniana jest najczęściej, z nielicznymi wyjątkami [10], krótko po jej zakończeniu, a to obniża wiarygodność oceny. Prezentowane metody z zastosowaniem różnych zabiegów fizykalnych nie mogą być schematami, bo ich skuteczność zależy najczęściej od fazy choroby, a twierdzenie, że pod wpływem pola elektromagnetycznego następuje regeneracja chrząstki i kości, zdrowienie wiązadeł i ścięgien [13], nie jest poparte wystarczającymi dowodami naukowymi. Ocena wyników fizjoterapii ChZSK w grupach niejednorodnych jest nieobiektywna. Bardziej obiektywnym wskaźnikiem jest pomiar siły mięśni zginaczy i prostowników kolana oraz zakresu ruchów, ale warunkiem prawidłowej oceny jest wykonanie testów w stawie bezbolesnym. Na podkreślenie zasługują wnioski w skojarzonym leczeniu fizykalnym i farmakologicznym przezskórnym NLPZ [3, 4]. Pozytywnym efektem fizykoterapii w leczeniu zaawansowanej ChZSK jest możliwość intensyfikacji kinezyterapii i odstawienie lub zmniejszenie dawek leków przeciwbólowych i przeciwzapalnych, najczęściej niestety na krótki okres. Znaczenie skojarzonego leczenia fizjoterapii i farmakoterapii docenia Samborski [14], omawiając patogenezę i mechanizmy rozwoju ChzS z towarzyszącymi im okresowymi odczynami zapalnymi. Analiza porównawcza wyników w tabelach 2 i 3 wskazuje na istotny wpływ NLPZ na natężenie bólu. Podkreśla się również niekorzystny wpływ znacznej nadwagi na skuteczność fizykoterapii [15]. Za właściwe należy uznać wnioski zawarte w pracy Popa i wsp., w których mowa o tym, że nieprzestrzeganie standardów leczenia zachowawczego generuje zbędne koszty społeczne przy miernych efektach [16]. Porównanie wyników zawartych w tabeli 4 wskazuje na istotną różnicę w redukcji bólu na korzyść pobytów szpitalnych i sanatoryjnych [10].

Niezmiernie istotna jest umiejętność obiektywnej oceny własnej działalności pod kątem określenia proporcji nakładu sił i środków (także finansowych) a uzyskiwanymi efektami. Brak postępów terapeutycznych powinien wymusić modyfikację postępowania poprzez włączenie do procesu leczniczego tego specjalisty, który w danym momencie jest w stanie leczenie zdynamizować. Tą osobą jest najczęściej ortopeda. Kontynuowanie leczenia zachowawczego w sytuacji stopniowej utraty prawidłowego przebiegu osi mechanicznej, pojawienia się niestabilności oraz braku pełnego wyprostu jest najczęściej popełnianym błędem. Nieprawidłowa oś plus niestabilność nawet nieznaczna to coraz szybsza degradacja stawu. Przenoszenie obciążeń i zmiana naprężeń koncentrują się w jednym z przedziałów stawu [17, 18]. Narastający ból zwiększa utykanie. Uwzględniając sprzężenia łańcuchów kinematycznych, zaburzenia w wyznacznikach chodu rozszerzają się stopniowo na staw biodrowy, skokowy, stawy stępu, dolny odcinek kręgosłupa i stawy kończyny przeciwnej. Stosowane techniki operacyjne, w tym wybór metody, uzależnione są od objawów klinicznych, okresu choroby i kryteriów biomechanicznych. Artroza jednoprzedziałowa przyśrodkowa (najczęściej) czy boczna u osoby względnie młodej, aktywnej fizycznie, której towarzyszy przemieszczenie osi mechanicznej w płaszczyźnie czołowej przy zachowanej stabilności stawu i pełnym wyproście, powinna być zakwalifikowana do osteotomii korekcyjnej przywracającej jej prawidłowy przebieg [19]. Podkolanowa międzywięzadłowa osteotomia przyśrodkowa w kolanie szpotawym czy bardziej wymagająca technicznie osteotomia z dostępu bocznego wg Coventry w kolanie szpotawym z mierną boczną niestabilnością oddalają na wiele lat radykalny zabieg endoprotezoplastyki. Po takiej operacji powrót do kontynuowania leczenia zachowawczego ma pełne uzasadnienie i jest ono wtedy znacznie skuteczniejsze. Artroza przebiegająca z zachowaniem prawidłowej osi mechanicznej u osób po 65. r.ż. po osiągnięciu stadium zaawansowanego z dużą bolesnością, a szczególnie artroza ze znaczną szpotawością czy koślawością, przykurczami, powikłana niestabilnością, często z translacją, może mieć tylko jedne wskazanie: dwu- lub trójprzedziałowa alloplastyka stawu kolanowego.

\section{WNIOSKI}

1. Ocena wyników fizjoterapii, a szczególnie izolowanej fizykoterapii, nie może opierać się na jednorazowym badaniu bezpośrednio po zakończeniu leczenia.

2. Wraz z nasileniem zmian chorobowych zmniejsza się skuteczność leczenia fizykalnego stawu kolanowego z chorobą zwyrodnieniową.

\section{PIŚMIENNICTWO}

1. Straburzyńska-Lupa A., Straburzyńska-Migaj E., Romanowska A.: Wpływ dwutygodniowej kinezyterapii na subiektywne odczucia bólu i sprawność ruchową u pacjentek z chorobą zwyrodnieniową stawów. Fizjoter Pol. 2004, 4 (1), 52-57.

2. Jasiak-Tyrkalska B., Frańczuk B., Jaworek J., Mosurska D.: Ocena skuteczności dwóch różnych zabiegów termoterapeutycznych w procesie postępowania rehabilitacyjnego w zmianach zwyrodnieniowych stawu kolanowego. Fizjoter Pol. 2004, 4 (2), 157-162.

3. Kujawa J., Talar J., Gworys K., Gworys P., Oborzyński J., Pieszyński I. et al.: Wpływ biostymulacji laserowej skojarzonej z wcierkami diclofenacu na wynik leczenia pacjentów z chorobą zwyrodnieniową stawu kolanowego. Fizjoter Pol. 2004, 4 (3), 185-193.

4. Szlachta M., Polak A., Błaszczyk B., Kluszczyńska-Galas A., Kubacki J., Król P.: Badanie skuteczności ultradźwięków i elektrofonoforezy we wspomaganiu leczenia choroby zwyrodnieniowej stawu kolanowego. Fizjoter Pol. 2009, 9 (3), 211-222. 
5. Gworys K., Gasztych J., Puzder A., Gworys P., Kujawa J.: Analiza wpływu różnych metod aplikacji promieniowania laserowego na dolegliwości bólowe i wydolność czynnościową stawu kolanowego w przebiegu choroby zwyrodnieniowej. Ortop Traumatol Rehabil. 2012, 14 (3), 269-277.

6. Boerner E., Ratajczak B., Chmiel M., Kuciel-Lewandowska J., Hawrylak A.: Ocena skuteczności krioterapii i magnetoterapii u chorych ze zmianami zwyrodnieniowymi stawów kolanowych. Acta Bio-Opt Inform Med. Inżynieria Biomedyczna. 2010, 16 (4), 310-313.

7. PasekJ., Mucha R., Sieroń A.: Magnetoledoterapia w leczeniu bólu zmian zwyrodnieniowych stawów kolanowych. Acta Bio-Opt Inform Med. 2006 12 (3), 189-191.

8. Łukowicz M., Ciechanowska K., Weber-Zimmermann M., Zalewski P.: Postępowanie fizykalne w chorobie zwyrodnieniowej stawu kolanowego. Kwart Ortop. 2008, 1, 8-16.

9. Bolach E., Grzonkowski J.: Wpływ kriogimnastyki na usprawnianie lecznicze kobiet ze zmianami zwyrodnieniowymi stawów kolanowych. Fizjoterapia. 2005, 13 (3), 57-66.

10. Czernicki J., Woldańska-Okońska M., Hyż L.: Ocena skuteczności podwójnie ślepej próby jonoforezy z diklofenaku zastosowanego u chorych ze zmianami zwyrodnieniowymi stawów kolanowych. Fizjoterapia. 2002, 10 (1), 5-11.

11. Kujawa J., Talar J., Gworys K., Gworys P., Pieszyński I., Janiszewski M.: Ocena skuteczności przeciwbólowej laseroterapii u chorych z chorobą zwyrodnieniową stawu kolanowego. Ortop Traumatol Rehabil. 2004, 6 (3), 356-366.
12. Lisiński P., Zapalski W., Stryła W.: Metody fizykalne w leczeniu bólu u chorych ze zwyrodnieniem stawów kolanowych. Ortop Traumatol Rehabil. 2005, 7 (3), 317-321.

13. Straburzyńska-Lupa A., Romanowski W., Romanowska A., Świetlik Z.: Ocena subiektywnego odczucia bólu i sprawności ruchowej u pacjentek z chorobą zwyrodnieniową stawów leczonych magnetoterapią i kinezyterapią. Fizjoter Pol. 2004, 4 (2), 151-156.

14. Samborski $W$ : Patogeneza choroby zwyrodnieniowej stawów - nowe metody leczenia i miejsce fizjoterapii. Baln Pol. 2001, 43 (3/4), 9-16.

15. Jasiak-Trykalska B., Frańczuk B., Jaworek J., Mosurska D.: Wskaźnik masy ciała (BMI) a skuteczność postępowania rehabilitacyjnego w zmianach zwyrodnieniowych stawu kolanowego. Ortop Traumatol Rehabil. 2004, 6 (4), 467-471.

16. Pop T., Szczygielska D., Drużbicki M., Zajkiewicz K.: Epidemiologia i koszty leczenia zachowawczego chorych z choroby zwyrodnieniowej stawów biodrowych i kolanowych. Ortop Traumatol Rehabil. 2007, 9 (4), 405-412.

17. Będziński R., Pozowski A., Ścigała K.: Badania doświadczalne przemieszczeń w rejonie stawu kolanowego. Biomechanika. 1994, 73, 14-19.

18. Pozowski A.: Badania kliniczne i doświadczalne nad międzywięzadłową osteotomią walgizującą "minus” w kolanie szpotawym. Redakcja Wydawnictw Uczelnianych Akad. Med. we Wrocławiu, Wrocław 2001.

19. Paley D., Maar D.C., Herzenberg J.E.: New concepts in high tibial osteotomy for medial compartment osteoarthriris. Orthop Clin North Am. 1994, 25 (3), 483-498. 